\title{
literature and medicine
}

\section{Dr Winkel's crucifix - moral ambiguity in The Third Man}

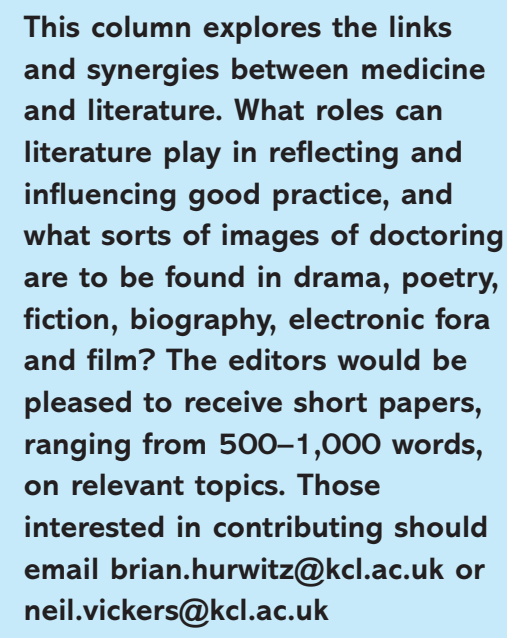

The Third Man is sometimes claimed to be 'the best British film ever made', with the British Film Institute voting it 'most loved film' in the millennial poll. ${ }^{1}$ Set in post-war Vienna, Graham Greene's plot centres on an illicit trade in antibiotics involving the enigmatic Dr Winkel. Is he simply the product of circumstances with values determined by self-preservation or does he represent the darker side of medicine in a time of crisis?

A fiction set in a factual context, it was filmed in 1948 in a city recovering from devastating bombing and a Soviet attack in which 37,000 soldiers were killed, creating a haunting backdrop of wintry ruins and legions of street dwellers. Divided into four zones by the Allied Powers, Vienna clearly displayed emerging tensions which would later characterise the Cold War. Greene and producer Alexander Korda, veterans of wartime espionage, incorporated two

Paul Dakin, general practitioner and trainer, Woodlands Medical Practice, London crucial realities - a black market trade in penicillin and a network of underground sewers used by racketeers. ${ }^{2}$

At the time, US intelligence was engaged in exchanging penicillin for information from a doctor in the Russian zone, the plot revolving around the theft, dilution and resale of the drug by a gang operating under the guise of a medical charity. ${ }^{3}$ This may seem strange in an age of easy access to antibiotics. Penicillin had been discovered in 1928 but was only used clinically on any scale in 1941, having been manufactured secretly for the military. ${ }^{4}$ In Vienna its supply was restricted to military hospitals which made it 'a highly sought commodity in a dangerous and dirty city full of potentially treatable infection' and, for this, Dr Winkel's expertise and contacts were essential. ${ }^{5}$ In one scene, the doctor is shown enjoying black market luxuries, answering enquiries with dismissive politeness, guarding his replies with closed statements and pedantically correcting the pronunciation of his surname. Greene's notes describe him as 'very precise, very neat, very clean and unforthcoming. A collector of religious objets d'art without any belief in religion. His statements are so limited that you can't for a moment doubt his veracity. ${ }^{6}$ Winkel displays the staid professional veneer of an old-fashioned medical practitioner but, complicit in murder, he is arrested for the misidentification of a body, fraudulently issuing a death certificate and for the dilution and distribution of stolen drugs.

But was the illicit trade in antibiotics really so bad? Did the racketeers not simply 'liberate' another scarce commodity - penicillin - rather than food or fuel? The investigating officer describes as 'murder' the devastating effects of the diluted drug - inadequately treated gangrene, puerperal sepsis and meningitis -

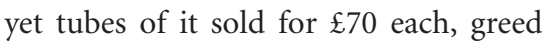
providing the prime motive. It is hard to imagine how difficult survival was during the degenerate chaos of that awful winter and it is tempting to excuse Winkel's self-preservation. But the incongruence of his actions with his calling sets the doctor apart from the tragic city dwellers who manage to live in frozen dereliction without resorting to criminality. This is why 'a moral reckoning must come in a critical study of the film. ${ }^{7}$

Visual clues are given that help to define the nature of such a reckoning beyond that of contrasting Winkel's prosperity with the city's poverty. Although he is seen as an unbeliever, religious artefacts can be found in his consulting room. In the original screenplay, Winkel speaks dismissively of his collection as dust and bones, but hints at more in his underlying character when he points out a Jansenist crucifix hanging on the wall. Greene indicates that 'the suffering Man's arms were pointing almost directly upwards, making their embrace very narrow' and distinguishing it from the traditional representation of Christ whose outstretched limbs signify acceptance and salvation. $^{8}$ (Jansenism is a heretical Catholic doctrine stressing a predestined and greatly restricted salvation..$^{9}$ ) Greene employs this visual device to suggest Winkel's alienation from God, that his actions are predestined, and that he is unable to place any value in morality or humanity.

The same moral ambiguity is shown when Orson Welles' Harry Lime looks down from the Reissenrade and asks whether his companion would feel pity if one of the 'dots', the people walking far below, stopped moving forever. Is Winkel here thinking that his patients including himself - are merely worthless 'dots' predestined to die? The Vienna of the film is only one generation removed from Freud's and we are invited to parallel Lime's exploration of the city's dark subconscious by descending with the plot into the murky 
sewers that run beneath its busy streets (see http://abluteau.files.wordpress.com / $2009 / 06 /$ third-man-welles - june14.jpg). Is Greene reflecting here his own struggle as an unconventional Catholic convert? In the original notes, the main character is invited to lecture at the Cultural Institute on 'The crisis of faith', reinforcing what Greene always spoke of, a 'risen-from-the dead story' referring not just to the faked funeral of Lime but also to the belief that hope would arise from the depths of moral crisis and despair.

If The Third Man is viewed simply as a thriller and these philosophical and theological dimensions are excluded, the author's impact upon the story is denied. By disclosing the hidden motives of a geographically literal and morally metaphorical subterranean manhunt, and showing a crisis, humanity and faith in an age without its old certainties, the 'post-war Vienna of The Third Man can be seen as a metaphor for the world in the twentieth century'. ${ }^{10}$ The film's rich moral dimensions, redolent of historical, political and military contexts, offer a medical humanities pretext to students and junior doctors to consider the many sides of professionalism and integrity in a world that offers unpredictable pressures and shifting values.

As Welles' Harry Lime says:

After all, it's not that awful-you know what the fellow said... In Italy for thirty years under the Borgias they had warfare, terror, murder, bloodshed - they produced Michaelangelo, Leonardo da Vinci and the Renaissance. In Switzerland they had brotherly love, five hundred years of democracy and peace, and what did that produce...? The cuckoo clock.

\section{Acknowledgement}

This article arises from research undertaken for the MA in Literature and Medicine, King's College London (www.kcl.ac.uk/schools/ humanities/depts/english/pg/masters/litmed. html).

\section{References}

1 Bud R. Penicillin: triumph and tragedy. Oxford: Oxford University Press, 2007:84.

2 Timmermann B. The Third Man's Vienna Vienna: Shippen Rock Publishing Ltd, 2005.

3 British Film Institute. The Vienna project right and sound, July 1999. www.bfi.org. uk/sightandsound/feature/169

4 Science Learning Network. The story of penicillin. www.sln.org/pieces/burr/startingpoint.htm

5 Drazin C. In search of The Third Man. London: Methuen Publishing Ltd, 1999.

6 Greene G. The Third Man and The Fallen Idol. London: Penguin Books, 1977.

7 White R. The Third Man. London: British Film Institute, 2003.

8 Greene G. The Third Man. London: Faber and Faber Ltd, 1988.

9 Elwell WA (ed.). Evangelical dictionary of theology. Carlisle: Paternoster Press, 1984.

10 Hoare J. The Third Man. York film notes. London: York Press, 2000.

Address for correspondence: Dr P Dakin, Woodlands Medical Practice, London N2 8BG.

Email: pdakin@nhs.net 